University of Nebraska - Lincoln

DigitalCommons@University of Nebraska - Lincoln

USDA National Wildlife Research Center - Staff Publications
U.S. Department of Agriculture: Animal and Plant Health Inspection Service

2016

\title{
Monitoring cryptic amphibians and reptiles in a Florida state park
}

\author{
Richard M. Engeman \\ USDA-APHIS-Wildlife Services, s_r100@yahoo.com \\ Walter E. Meshaka Jr. \\ State Museum of Pennsylvania \\ Robert Severson \\ Savannas Preserve State Park \\ Mary Ann Severson \\ Savannas Preserve State Park \\ Greg Kaufman \\ Florida Park Service
}

See next page for additional authors

Follow this and additional works at: https://digitalcommons.unl.edu/icwdm_usdanwrc

Part of the Life Sciences Commons

Engeman, Richard M.; Meshaka, Walter E. Jr.; Severson, Robert; Severson, Mary Ann; Kaufman, Greg; Groninger, N. Paige; and Smith, Henry T., "Monitoring cryptic amphibians and reptiles in a Florida state park" (2016). USDA National Wildlife Research Center - Staff Publications. 1816.

https://digitalcommons.unl.edu/icwdm_usdanwrc/1816

This Article is brought to you for free and open access by the U.S. Department of Agriculture: Animal and Plant Health Inspection Service at DigitalCommons@University of Nebraska - Lincoln. It has been accepted for inclusion in USDA National Wildlife Research Center - Staff Publications by an authorized administrator of DigitalCommons@University of Nebraska - Lincoln. 


\section{Authors}

Richard M. Engeman, Walter E. Meshaka Jr., Robert Severson, Mary Ann Severson, Greg Kaufman, N.

Paige Groninger, and Henry T. Smith 


\title{
Monitoring cryptic amphibians and reptiles in a Florida state park
}

\author{
Richard M. Engeman ${ }^{1} \cdot$ Walter E. Meshaka Jr. ${ }^{2} \cdot$ Robert Severson $^{3}$ • \\ Mary Ann Severson ${ }^{3} \cdot$ Greg Kaufman $^{4}$ • N. Paige Groninger ${ }^{1} \cdot$ Henry T. Smith $^{5}$
}

Received: 5 November 2015 / Accepted: 28 December 2015 / Published online: 6 January 2016

(C) Springer-Verlag Berlin Heidelberg (outside the USA) 2016

\begin{abstract}
We monitored cryptic herpetofauna at Savannas Preserve State Park, Florida, by combining artificial cover counts with a quantitative paradigm for constructing and calculating population indices. Weekly indices were calculated from two consecutive days of data collection each week for 7 months from mid-winter to mid-summer in three habitats. Seventeen species were observed at least once, and time trends using index values were followed for six species. Among these, abundance and seasonal pattern information were obtained for an exotic species (greenhouse frog) and a species identified by the Florida Committee on Rare and Endangered Plants and Animals as threatened (Florida scrub lizard). We identified winter as the optimal time in this area to monitor populations for conducting annual assessments. This combined observation and indexing approach could provide managers or researchers with an economical means to
\end{abstract}

Responsible editor: Thomas Hein

Henry T. Smith is deceased.

Richard M. Engeman

richard.m.engeman@aphis.usda.gov

1 National Wildlife Research Center, 4101 LaPorte Ave, Fort Collins, CO 80521-2154, USA

2 Section of Zoology and Botany, The State Museum of Pennsylvania, 300 North Street, Harrisburg, PA 17120-0024, USA

3 Savannas Preserve State Park, 9551 Gumbo Limbo Lane, Jensen, Beach, FL 34957, USA

4 Florida Department of Environmental Protection, Florida Park Service, 3900 Commonwealth Boulevard, Tallahassee, Fl 32399, USA

5 Florida Department of Environmental Protection, Florida Park Service, 13798 S.E. Federal Highway, Hobe Sound, FL 33455, USA quantitatively index population trends for multiple cryptic herpetofauna species simultaneously. Using artificial cover to sample within a population indexing design can be generalized beyond monitoring herpetofauna. Other forms of artificial cover that can be used as observation stations include aquatic artificial substrates, artificial tree cavities, artificial reefs, and other artificial aquatic structures and artificial sea grass units, among many others, and a wide range of taxa are suitable for population monitoring using artificial cover as observation stations in the approach we present, including insects, soil invertebrates, micro and macro aquatic invertebrates, fish, crustaceans, and small mammals.

Keywords Abundance index - Conservation - Coverboard · Endangered species · Exotic species · Invasive species · Population monitoring

\section{Introduction}

Many amphibians and reptiles are cryptic and difficult to observe. As is the case throughout the field of wildlife biology, monitoring their population trends can be vital for management and research purposes. Of particular importance is the ability to detect and monitor abundance and range changes for both exotic and endangered species, although management objectives would differ greatly between them. Conservation efforts typically begin with an inventory, followed by monitoring and management. The same logical sequence is applicable for managing exotic species. In either case, standardized repeatable procedures are necessary to produce quantitative data that can be validly compared across sampling occasions (e.g., Engeman 2005).

The use of coverboards is a valuable technique to detect, observe, and collect cryptic herpetofauna. For some species, 
coverboards are the most reliable means of observation (e.g., Sutton et al. 1999). Many herpetofauna species use naturally occurring structures for cover. While such natural cover structures provide valuable opportunities to locate and observe animals, repeated disturbance for such purposes can degrade their functionality for the species using them (e.g., Guilfoyle 2010). Moreover, naturally occurring cover structures are highly variable in size and composition, which can introduce substantial variability and/or confounding into sampling (see comments by Engeman 2005). Use of artificial cover can provide consistency in sampling and observation procedures without degrading natural cover structures. We applied artificial cover methodology in the form of coverboards as a lowlabor, low-cost method to simultaneously index multiple cryptic herpetofauna species in a south Florida park from winter to summer. We specifically designed the sampling to produce suitable data for the application of the general indexing procedures outlined by Engeman (2005), and we demonstrate its utility for indexing and monitoring cryptic herpetofauna with coverboard observations. The resulting index values calculated from the coverboard data were used to examine population behaviors across seasons and to indentify the optimal time of year to conduct year-to-year population assessments.

Briefly, the indexing paradigm (Engeman 2005) is a straight-forward procedure for structuring sampling, making observations at each sampling location, and analyzing the resulting data according to the statistically derived formulae reliant on minimal assumptions. The approach is very general and has been, and can be, applied for monitoring an immense array of wildlife species using a diversity of observation methods including cameras, tracking stations, bait take, visual observations, and many more (e.g., Allen et al. 2013, 2014; Baldwin et al. 2014; Engeman et al. 2000, 2001, 2003, 2006; Engeman and Whisson 2003). Here, our monitoring of cryptic herpetofauna species also demonstrates the method's utility for using observations from coverboards.

\section{Methods}

\section{Study area}

The study was conducted in Savannas Preserve State Park (SPSP), a 2116-ha park located along the coast of southeast Florida in St. Lucie and Martin counties. SPSP is comprised of a mix of natural communities including mesic flatwoods (889 ha), ephemeral basin marsh (644 ha), wet prairie (149 ha), scrubby flatwoods (63 ha), and sand pine-oak scrub (180.5 ha) (Florida Department of Environmental Protection 2003; Florida Natural Areas Inventory 2010). SPSP is home to at least 30 herpetofauna species (Florida Department of Environmental Protection 2003).

\section{Artificial cover design and placement}

We used $1.22 \mathrm{~m} \times 1.22 \mathrm{~m} \times 1.27 \mathrm{~cm}$ chemically untreated plywood boards as coverboards. To sample a variety of species, 30 coverboards were placed in SPSP in December 2003, 10 each along transects through three habitat settings. Ten were placed along the interface between mesic flatwoods and wet prairie habitats (Florida Natural Areas Inventory 2010) in a relatively linear fashion and roughly parallel to an approximately $4.8 \mathrm{~km}$ of hiking trail. These coverboards had a southern/western exposure, receiving sun and shade through the day. Another 10 were placed along the western edge of the ephemeral basin marsh (Florida Natural Areas Inventory 2010) at about $1 \mathrm{~m}$ from the water's edge. These coverboards received morning to early afternoon sun. The final set of 10 were placed along a transect following the Atlantic Coastal Ridge in sand pine-oak scrub (Florida Natural Areas Inventory 2010), with the coverboards placed on the east edges of oak scrub patches to receive morning sun and partial afternoon shade. Coverboards in each habitat were placed a minimum of $70 \mathrm{~m}$ apart. This inter-board distance was sufficient for the coverboards to be considered independent for most of the species observed, although independence is not a necessary assumption for the index calculations described in the next section (Engeman 2005). All coverboard locations were recorded by GPS. Observations commenced on 28 December 2003. The numbers of each herpetofauna species were counted under each coverboard for two consecutive days on an approximate weekly basis through 2 July 2004. Coverboards were checked beginning at 7:30-8:30 a.m. and concluding by late morning. The same order was used each day to ensure index values across time were not confounded by an observation order effect (i.e., the order in which a coverboard was observed was considered a characteristic of the board in the same manner as its geographical location).

\section{Index calculations}

The numbers of individuals of each species under each coverboard was used as the observation variables in the same manner that intrusions to passive tracking plots have been used in index calculations (e.g., Engeman et al. 2000). The daily number of individuals of each species observed under each coverboard provided an appropriate data structure for calculating a coverboard abundance index (CAI) for each habitat according to the analytical methods outlined in Engeman (2005) and as extensively applied for passive tracking and camera indices (e.g., Engeman et al. 2000, 2001, 2003, 2006). The mean number observed across stations for each species was calculated for each day. The index value for each species at a given sampling occasion was calculated as the 
mean of the daily means as represented in the following index formula:

$\mathrm{CAI}=\frac{1}{d} \sum_{j=1}^{d} \frac{1}{s_{j}} \sum_{i=1}^{s j} x_{i j}$

where $x_{i j}$ represents the number of individuals of species $x$ at the $i$ th coverboard station on the $j$ th day, $d$ is the number of days of observation ( $d=2$ in our case), and $s_{j}$ is the number of stations contributing data on the $j$ th day $\left(s_{j}=10\right.$ for each habitat). The resulting index values for each species through time and in different habitats can be viewed in various ways. As presented by Engeman (2005) and exemplified in broad applications by Allen et al. $(2013,2014)$, index values form a succinct means to describe trends in activity across time and habitats. In particular, our interest was to descriptively examine coverboard activity of herpetofauna species across seasons and in three habitats. We note that if we had well-defined a priori comparisons that we wished to make between select index values, then the theory and calculation procedures for carrying out such comparisons are presented in Engeman (2005) and many subsequent articles. Pursuing such comparisons of index values without a predetermined design for specific comparisons would present a substantial multiple comparison problem, especially considering that for just one species in one habitat over the time course of our study presents 325 potential comparisons.

\section{Results}

Seventeen species of amphibians $(n=6)$ and reptiles $(n=11)$ were detected through the course of the study (Table 1). Among the species commonly observed were an exotic species (in all three habitats), the greenhouse frog (Eleutherodactylus planrostris) (Meshaka 2011), and a species identified as threatened by the Florida Committee on Rare and Endangered Plants and Animals (but observed in only one habitat), the Florida scrub lizard (Sceloporus woodi) (DeMarco 1992; Branch and Hokit 2008). The ground skink (Scincella lateralis) was the most frequently observed species, followed by the greenhouse frog, with these two species by far the two most frequently observed. The next most frequently observed species were Florida cricket frogs (Acris gryllus), ringneck snakes (Diadophis punctatus), and peninsula ribbon snakes (Thamnophis sauritus). Oak toads (Anaxyrus quercicus), a species prone to population declines in areas where development takes place (Delis et al. 1996; Wilson and Porras 1983), and Southern leopard frogs (Lithobates sphenocephalus) were regularly observed, but not with the frequency of the preceding species (Table 1). Most species were observed in only one of the three habitat placements
(Table 1). The ground skink (native) and the greenhouse frog (exotic) were the only species found in all three habitats.

We calculated and evaluated weekly index values for the six most frequently observed species to gain insight on their activities from winter to summer (Table 2). Because both greenhouse frogs and ground skinks were observed in each habitat, indices were calculated separately within each habitat for each species. Greenhouse frogs were by far most plentiful in the mesic flatwood-wet prairie interface than in the other two habitats (Tables 1 and 2), with $91 \%$ observations located there. In the mesic flatwood-wet prairie interface, index values increased sharply from December through February, but with substantial fluctuations. From March to May, index values were in a comparative mid-range, again with fluctuations of considerable relative amplitude. After May, index values were low, concomitant with egglaying (Meshaka and Layne 2005), which involves caring for the nest by the female (Goin 1947). Index values for the other two habitats were most often 0 , although late January through February saw the values for the basin marsh roughly parallel the results for the mesic flatwood-wet prairie interface, but on a much lesser scale.

Cricket frogs were another commonly observed amphibian species and were found in the mesic flatwood-wet prairie interface and the basin marsh habitats, with $60 \%$ of the observations in the mesic flatwood-wet prairie interface (Tables 1 and 2). Like a variety of other species, this one was only observed early in the year with no observations after mid-March in either habitat.

Total ground skink observations were similar for the mesic flatwood-wet prairie interface and the basin marsh (Table 1). After mid-March, index values for the two habitats were very similar. Peak index values were higher prior to March in both habitats, but not in phase with each other. Ground skinks were not observed in the sand pine-oak scrub habitat after midFebruary. Florida scrub lizards were observed prior to May and only in the sand pine-oak scrub habitat, with fluctuating, almost cyclic, index values. The species was not observed under our coverboards after the end of April (Table 2).

The two most regularly observed snakes were the ringneck snake followed by the peninsula ribbon snake (Tables 1 and 2). Both snakes were observed only in the basin marsh early in the year, with the ringneck snake tending to have higher index values (Table 2). Only one ribbon snake was observed after mid-February and no ringneck snakes were observed after mid-March (Table 2).

\section{Discussion}

We applied coverboards to collect observations on multiple herpetofauna species across seasons in a south Florida state park. In doing so, we demonstrated a practical in-field 
Table 1 Summary of the number of coverboards under which each species was found in three habitats at Savannas Preserve State Park, St. Lucie and Martin counties, Florida

\begin{tabular}{|c|c|c|c|c|c|}
\hline \multirow[t]{2}{*}{ Species detected } & \multirow[t]{2}{*}{ Common name } & \multicolumn{4}{|c|}{ Number observed } \\
\hline & & Total & Mesic flatwood/wet prairie & Basin marsh & Sand pine-oak scrub \\
\hline Anaxyrus quercicus & Oak toad & 8 & 5 & 3 & \\
\hline Anaxyrus terrestris & Southern toad & 4 & & 4 & \\
\hline Acris gryllus dorsalis & Cricket frog & 15 & 9 & 6 & \\
\hline Pseudacris ocularis & Little grass frog & 1 & 1 & & \\
\hline Eleutherodactylus planrostris ${ }^{\mathrm{E}}$ & Greenhouse frog & 94 & 86 & 6 & 2 \\
\hline Lithobates sphenocephalus & Southern leopard frog & 8 & 5 & 3 & \\
\hline Ophisaurus ventralis & Eastern glass lizard & 4 & & 4 & \\
\hline Hemidactylus garnotii $^{\mathrm{E}}$ & Indo-pacific gecko & 5 & & & 5 \\
\hline Anolis carolinensis & Green anole & 2 & & & 2 \\
\hline Sceloporus woodi ${ }^{\mathrm{R}}$ & Florida scrub lizard & 13 & & & 13 \\
\hline Plestiodon inexpectatus & Southeastern five-lined skink & 1 & & & 1 \\
\hline Scincella lateralis & Ground skink & 106 & 49 & 53 & 4 \\
\hline Diadophis punctatus & Ringneck snake & 21 & & 21 & \\
\hline Thamnophis sauritus & Ribbon snake & 10 & & 10 & \\
\hline Coluber constrictor & Eastern racer & 3 & & 3 & \\
\hline Pantherophis guttatus & Eastern corn snake & 1 & 1 & & \\
\hline Sistrurus miliaris & Pigmy rattlesnake & 1 & 1 & & \\
\hline
\end{tabular}

$E$ exotic species, $R$ rare or otherwise of concern

sampling and observational method that we designed so that a quantitatively valid analysis to produce population indices could be applied. These results simultaneously illustrated the population behaviors of multiple cryptic herpetofauna species across seasons (Table 2) and also identified the optimal time of year to carry out surveys to assess populations over time.

Using 10 coverboards per habitat, we succeeded in detecting 17 species of amphibians and reptiles and we indexed six species over time, including an exotic species and a native species with vulnerable populations. The use of a larger number of coverboards over larger areas and sampling other habitats may result in an even greater number of species being observed on a consistent basis, thereby broadening the ability to monitor population trends through time.

If populations of various species of herpetofauna are to be monitored over years, the assessments should be at the same time each year to avoid confounding seasonal effects with trends over years (Engeman 2005). For our study location in south Florida, the winter months would be the optimal time to conduct annual coverboard surveys, because this is when maximal usage of the coverboards by the most species took place. There are multiple plausible explanations for the decline in coverboard usage from winter to summer. It may be that the coverboards were attractive resources during the overwintering process. For some species, such as the greenhouse frog, the decline in usage may also be related to breeding behavior. In other circumstances, our $1.27-\mathrm{cm}$-thick plywood boards may not have offered sufficient protection from increasing ambient temperatures and reflected heat, especially in the sand pine-scrub oak habitat, or possibly even in the basin marsh where coverboards were more in open sunshine. Whatever the reason, advance knowledge of this decline in coverboard use by many species as the seasons change from winter to spring (roughly by March) is valuable design information for guiding annual surveys using coverboards in this region.

Assessment of the status and impact of exotic species, especially those that are invasive, is a key management issue in many places. Florida is fraught with exotic species of amphibians and reptiles, especially lizards (e.g., Meshaka 2011; Engeman et al. 2011). The number of non-native lizard species breeding in Florida now exceeds the number of native species, with over three times as many exotic species as native in south Florida (Hardin 2007). Many exotic species have expanded populations and geographic ranges to an apparent point of no return, leading to current multi-agency discussions for developing early detection-rapid response plans for addressing the most threatening of invasive species introductions. Although Florida stands out with a preponderance of exotic herpetofauna species, exotic amphibians and reptiles are common through many parts of the world (e.g., Kraus 2009). A means to detect and quantitatively monitor exotic herpetofauna would be useful for assisting management to define the breadth of a problem and need for action, optimize 
Table 2 Coverboard index values for the six most commonly observed herpetofauna species in Savannas Preserve State Park, Florida

\begin{tabular}{|c|c|c|c|c|c|c|c|c|c|c|c|}
\hline \multirow[t]{2}{*}{ Date } & \multicolumn{3}{|c|}{ Greenhouse frog } & \multicolumn{2}{|c|}{ Cricket frog } & \multicolumn{3}{|c|}{ Ground skink } & \multirow{2}{*}{$\begin{array}{l}\text { Florida scrub lizard } \\
\text { SP-OS }\end{array}$} & \multirow{2}{*}{$\begin{array}{l}\text { Ring-neck snake } \\
\text { BM }\end{array}$} & \multirow{2}{*}{$\begin{array}{l}\text { Ribbon snake } \\
\text { BM }\end{array}$} \\
\hline & MF-WP & $\mathrm{BM}$ & SP-OS & MF-WP & $\mathrm{BM}$ & MF-WP & $\mathrm{BM}$ & SP-OS & & & \\
\hline 29 Dec & .05 & 0 & 0 & 0 & 0 & .2 & .05 & .05 & .1 & 0 & .1 \\
\hline 14 Jan & .25 & 0 & 0 & 0 & 0 & .15 & 0 & .1 & 0 & .05 & .05 \\
\hline $21 \mathrm{Jan}$ & .2 & 0 & .05 & .1 & .05 & .2 & 0 & 0 & .05 & .1 & 0 \\
\hline 29 Jan & .05 & 0 & 0 & .05 & .1 & .1 & .25 & 0 & 0 & 0 & .1 \\
\hline $4 \mathrm{Feb}$ & .35 & 0 & .05 & .05 & .15 & .05 & .15 & .05 & .05 & .05 & .05 \\
\hline $10 \mathrm{Feb}$ & .25 & .05 & 0 & .05 & 0 & .05 & .25 & 0 & .2 & .15 & .1 \\
\hline $17 \mathrm{Feb}$ & .5 & 0 & 0 & 0 & .05 & .05 & .1 & 0 & .05 & .3 & 0 \\
\hline $25 \mathrm{Feb}$ & .55 & .1 & 0 & 0 & 0 & .25 & .25 & 0 & 0 & .05 & 0 \\
\hline $1 \mathrm{Mar}$ & .45 & 0 & 0 & 0 & 0 & .15 & .55 & 0 & .05 & .25 & 0 \\
\hline $12 \mathrm{Mar}$ & .05 & 0 & 0 & .05 & 0 & .2 & .2 & 0 & 0 & .1 & 0 \\
\hline 19 Mar & .26 & .05 & 0 & .05 & 0 & .1 & .1 & 0 & .05 & 0 & 0 \\
\hline 27 Mar & .2 & 0 & 0 & .05 & 0 & 0 & 0 & 0 & 0 & 0 & 0 \\
\hline $4 \mathrm{Apr}$ & .05 & 0 & 0 & 0 & 0 & .2 & .15 & 0 & .05 & 0 & 0 \\
\hline $8 \mathrm{Apr}$ & .25 & 0 & 0 & 0 & 0 & 0 & .05 & 0 & 0 & 0 & 0 \\
\hline $15 \mathrm{Apr}$ & .05 & 0 & 0 & 0 & 0 & .15 & .1 & 0 & .05 & 0 & 0 \\
\hline $22 \mathrm{Apr}$ & .05 & 0 & 0 & 0 & 0 & .05 & 0 & 0 & 0 & 0 & 0 \\
\hline $29 \mathrm{Apr}$ & .31 & 0 & 0 & 0 & 0 & .1 & .1 & 0 & 0 & 0 & .05 \\
\hline 4 May & .05 & 0 & 0 & 0 & 0 & .05 & .1 & 0 & 0 & 0 & 0 \\
\hline 13 May & .05 & 0 & 0 & 0 & 0 & .05 & .05 & 0 & 0 & 0 & 0 \\
\hline 18 May & 0 & .05 & 0 & 0 & 0 & .15 & .1 & 0 & 0 & 0 & 0 \\
\hline 28 May & .05 & 0 & 0 & 0 & 0 & .05 & .05 & 0 & 0 & 0 & 0 \\
\hline 6 Jun & .05 & .05 & 0 & 0 & 0 & .05 & 0 & 0 & 0 & 0 & 0 \\
\hline 9 Jun & 0 & 0 & 0 & 0 & 0 & 0 & 0 & 0 & 0 & 0 & 0 \\
\hline 18 Jun & 0 & 0 & 0 & 0 & 0 & .05 & 0 & 0 & 0 & 0 & 0 \\
\hline 24 Jun & .05 & 0 & 0 & 0 & 0 & 0 & 0 & 0 & 0 & 0 & 0 \\
\hline $2 \mathrm{Jul}$ & 0 & 0 & 0 & 0 & 0 & 0 & 0 & 0 & 0 & 0 & 0 \\
\hline
\end{tabular}

The habitat from which the data were collected are indicated by $M F-W P$ interface between mesic flatwoods and wet prairie habitats, $B M$ basin marsh, and $S P-O S$ sand pine-oak scrub interface

the timing and placement of management actions to address a problem, and to help evaluate the success of the management actions (e.g., Engeman 2005; Kraus 2009; Meshaka 2013).

Conservation of rare species is another key management issue. A systematic means to detect, observe, and quantify numbers for rare and vulnerable species also is a valuable management tool. Knowledge of whether such a population is stable, increasing, or decreasing can assist the decisionmaking process for timing and placement of management actions to aid in species conservation. Simultaneous monitoring of multiple coexisting species can help identify relationships among species that might be useful for conservation approaches.

Using artificial cover to sample within a population indexing design can be generalized beyond monitoring herpetofauna. Many other forms of artificial cover can be used as observation stations to monitor many taxa and include aquatic artificial substrates, artificial tree cavities, artificial reefs and other artificial aquatic structures and artificial sea grass units, among many others, and a wide range of taxa are suitable for population monitoring using artificial cover as observation stations in the approach we present, including insects, soil invertebrates, micro and macro aquatic invertebrates, fish, crustaceans, and small mammals (CzerniawskaKusza 2004; De Pauw et al. 1986; Ferguson and Berube 2004; Kenyon et al. 1999; Larson et al. 1986; Loretto and Vinícius Vieira 2011; Moulton II et al. 2002; Tester et al. 2014; Yanoviak and Fincke 2005).

\section{Conclusions}

We found application of coverboards, as a tried-and-true method for detecting and observing cryptic herpetofauna, to also serve well to quantitatively index herpetofauna populations when used in a general observational and measurement 
design for developing population indices (Engeman 2005). This application carried out in a south Florida state park not only was effective for detecting many cryptic herpetofauna species but also effectively was able to simultaneously show trends for multiple species across seasons from winter to summer. By examining these results, we were able to identify winter as the optimal time of year in which to use the method for monitoring cryptic herpetofauna species across years in this area. Annual monitoring across years would be especially valuable for determining and assessing management actions towards rare species and invasive species. The method is widely applicable to many other taxa where artificial cover of some form could be used for observation stations.

\section{References}

Allen BL, Allen LR, Engeman RM, Leung LKP (2013) Intraguild relationships between sympatric predators exposed to lethal control: predator manipulation experiments. Front Zool 10:39

Allen BL, Allen LR, Engeman RM, Leung LK-P (2014) Sympatric prey responses to lethal top-predator control: predator manipulation experiments. Front Zool 11:56

Baldwin RA, Quinn N, Davis DH, Engeman RM (2014) Effectiveness of rodenticides for managing invasive roof rats and native deer mice control in orchards. Environ Sci Pollut Res 21:5795-5802

Branch LC, Hokit DG (2008) Florida scrub lizard (Sceloporus woodi), Document WEC 139. Florida Cooperative Extension Service, Institute of Food and Agricultural Sciences. University of Florida, Gainesville, FL

Czerniawska-Kusza I (2004) Use of artificial substrates for sampling benthic macroinvertebrates in the assessment of water quality of large lowland rivers. Pol J Environ Stud 13(5):579-584

De Pauw N, Roels D, Fontoura AP (1986) Use of artificial substrates for standardized sampling of macroinvertebrates in the assessment of water quality by the Belgian Biotic Index. Hydrobiologia 133:237-258

Delis PR, Mushinsky HR, McCoy ED (1996) Decline of some westcentral Florida anuran populations in response to habitat degradation. Biodivers Conserv 5:1579-1595

DeMarco V (1992) Florida scrub lizard. In: Moler P (ed) Rare and Endangered Biota of Florida, vol III, Amphibians and Reptiles. University Press of Florida, Gainesville, Florida, pp 141-145

Engeman RM (2005) A methodological and analytical paradigm for indexing animal populations applicable to many species and observation methods. Wildl Res 32:203-210

Engeman RM, Whisson DA (2003) A visual method for indexing muskrat populations. Int Biodeterior Biodegrad 52:101-106

Engeman RM, Pipas MJ, Gruver KS, Allen L (2000) Monitoring coyote populations with a passive activity index. Wildl Res 27:553-557

Engeman RM, Constantin B, Nelson M, Woolard J, Bourassa J (2001) Monitoring changes in feral swine population and spatial distribution of activity. Environ Conserv 28:235-240

Engeman RM, Martin RE, Constantin B, Noel R, Woolard J (2003) Monitoring predators to optimize their management for marine turtle nest protection. Biol Conserv 113:171-178

Engeman RM, Woolard JW, Perry ND, Witmer G, Hardin S, Brashears L, Smith HT, Muiznieks B, Constantin BU (2006) Rapid assessment for a new invasive species threat: the case of the Gambian giant pouched rat in Florida. Wildl Res 33:439-448
Engeman RM, Jacobson E, Avery M, Meshaka WE Jr (2011) The aggressive invasion of exotic reptiles in Florida with a focus on prominent species: a review. Curr Zool 57:599-612

Ferguson SH, Berube DKA (2004) Invertebrate diversity under artificial cover in relation to boreal forest habitat characteristics. Can Field Nat 118(3):386-394

Florida Department of Environmental Protection (2003) Savannas Preserve State Park management plan, Florida Department of Environmental Protection. Florida Park Service, Tallahassee, FL

FNAI (Florida Natural Areas Inventory) (2010) Guide to the natural communities of Florida. Florida Natural Areas Inventory and Florida Department of Natural Resources, Tallahassee, FL, http://www. fnai.org/natcom_accounts.cfm

Goin CB (1947) Studies on the life history of Eleutherodactylus ricordii planirostris (Cope) in Florida. Univ Fla Stud Biol Sci Ser 4:1-66

Guilfoyle MP, Ecosystem Management and Restoration Research Program (2010) Implementing herpetofaunal inventory and monitoring efforts on Corps of Engineers project lands. U.S. Army Corps of Engineers, Washington, DC

Hardin S (2007) Managing non-native wildlife in Florida: state perspective, policy and practice. In: Witmer G, Pitt W, Fagerstone K (eds) Managing Vertebrate Invasive Species: Proceedings of an International Symposium Fort Collins, CO. USDA/APHIS/WS, National Wildlife Research Center, pp 43-52

Kenyon RA, Haywood MDE, Heales DS, Loneragan NR, Pendrey RC, Vance DJ (1999) Abundance of fish and crustacean postlarvae on portable artificial seagrass units: daily sampling provides quantitative estimates of the settlement of new recruits. J Exp Mar Biol Ecol 232:197-216

Kraus F (2009) Alien reptiles and amphibians: a scientific compendium and analysis. Springer, New York

Larson EW, Johnson DL, Lynch WE Jr (1986) A buoyant pop net for accurately sampling fish at artificial habitat structures. Trans Am Fish Soc 115:351-355

Loretto D, Vinícius Vieira M (2011) Artificial nests as an alternative to studies of arboreal small mammal populations: a five-year study in the Atlantic Forest. Brazil Zoologia 28(3):388-394

Meshaka WE Jr (2011) Runaway train in the making: the exotic amphibians, reptiles, turtles, and crocodilians of Florida. Monograph 1. Herpetol Conserv Biol 6:1-101

Meshaka WE Jr (2013) The exotic amphibians and reptiles of the United States. In: Graeter GJ, Bulhmann KA, Wilkinson LR, Gibbons JW (eds) Inventory and Monitoring: Recommended Techniques for Reptiles and Aamphibians. Partners in Amphibian and Reptile conservation Technical Publication IM-1, Birmingham, Alabama, pp 20-27

Meshaka WE Jr, Layne JN (2005) Habitat relationships and seasonal activity of the greenhouse frog, Eleutherodactylus planirostris, in southern Florida. Fla Sci 68:35-43

Moulton SR II, Kennen JG, Goldstein RM, Hambrook JA (2002) Revised protocols for sampling algal, invertebrate, and fish communities as part of the National Water-Quality Assessment Program, Open-File Report 02-150 U.S. Department of the Interior U.S. Geological Survey, Reston, VA

Sutton PE, Mushinsky HR, McCoy ED (1999) Comparing the use of pitfall drift fences and coverboards for sampling the threatened sand skink (Neoseps reynoldsi). Herpetol Rev 30:149-151

Tester PA, Kibler SR, Holland WC, Usup G, Vandersea MW, Leaw CP, Teen LP, Larsen J, Mohammad-Noor N, Faust MA, Litaker RW (2014) Sampling harmful benthic dinoflagellates: comparison of artificial and natural substrate methods. Harmful Algae 39:8-25

Wilson LD, Porras L (1983) The ecological impact of man on the South Florida herpetofauna. Univ Kansas Mus Nat Hist Spec Publ 9:1-89

Yanoviak SP, Fincke OM (2005) Sampling methods for water-filled tree holes and their artificial analogues In: Lawton JH, Likens GE (eds) Methods in Ecology: Insect Sampling in Forest Ecosystems, Blackwell Pp 168-185. 